\title{
周術期のリハビリテーション中に発生した致死的肺塞栓症
}

\author{
高野裕一*1 山平 斉*2
}

\section{Fatal Pulmonary Embolism during the Perioperative Rehabilitation}

\author{
Yuichi TAKANO, ${ }^{* 1}$ Hitoshi YamahIRA*2
}

\begin{abstract}
Fatal pulmonary embolism is a well known complication of various disorders, including orthopedic surgical cases. We present two cases of pulmonary embolism occurring in the perioperative periods. Case 1: A 66-year-old woman suffering from intraduralextramedullary tumor at the level of Th 9 complained of gait disturbance. On the sixth day after tumor resection, cardiopulmonary arrest occurred immediately after muscle manual test of lower limb. She expired despite resuscitation. Pulmonary embolism was suggested. Case 2: A 80-year-old woman suffered from right hip fracture. Six days after admission, she experienced dyspnea and chest pain during muscle strengthening exercise of upper limb. Pulmonary embolism was diagnosed based on defective images in the right upper lobes on urgent pulmonary blood flow scintigram. Her clinical status improved with urgent anticoagulation therapy (with heparin). Special attention should be paid to prophylaxis of pulmonary embolism in patients in the perioperative periods. Intermittent pneumatic compression and therapeutic exercises offers advantages over pharmacological prophylaxis against venous thromboembolism-namely, safety, absence of bleeding complications, and efficacy in reducing calf thrombosis. Early rehabilitation should be recommended by means of thromboprophylaxis. (Jpn J Rehabil Med 2001; 38 : 42-45)
\end{abstract}

Key words : 肺塞栓症 (pulmonary embolism), 周術期 (perioperative period), 血栓予 防 (thromboprophylaxis), 運動療法 (therapeutic exercise), 早期リハビ リテーション (early rehabilitation)

はじめに

欧米では，下肢手術の術後合併症の 1 つである肺塞 栓症は積極的に予防的治療が行われている ${ }^{1,2)}$. 本邦 では周術期肺塞栓症の発生についての報告は少ない が, 術後肺塞栓の発生率は高く, 時に致死的であるた め今後患者に説明し予防をする必要がある ${ }^{3)}$. 今回, 周術期のリハビリテーション中に意識消失，心肺停止 で発症した致死的肺塞栓症を含む 2 例を報告し考察を 加える.

\section{症例}

症例 $1 ： 66$ 歳女性, 1997 年 10 月両下肢しびれが出
現し，徐々に両下肢筋力低下が進行し，同年 2 月歩行 障害のため当科入院した。既往歴は，胆石による胆囊 摘出術と高血圧で，家族歴に特記すべきことはなかっ た。 入院時現症は, 身長 $147 \mathrm{~cm}$, 体重 $63 \mathrm{~kg}$ で, 両 体幹の臍部以下に異常知覚と, 徒手筋力テストで 2 の 両下肢筋力低下を認めた。胸部 X 線, 血液生化学検 查, 心電図は異常なく, 呼吸機能は 1 秒量 $2,270 \mathrm{cc}$, 1 秒率 $79.6 \%$ だった。深部静脈血栓症を疑う下肢腫脹 を認めなかった.MRI および脊髄造影で第 9 胸椎レ ベルの硬膜内髄外腫瘍と診断し, 第 8 10 胸椎椎弓切 除後に硬膜切開し腫瘍摘出術を施行した. 手術時間 2 時間, 出血時間 $70 \mathrm{ml}$ で, 術中, 術直後の経過は良好 であった。病理学的には硬膜内髄外髄膜腫であった。

2000 年 7 月 17 日受付, 2000 年 10 月 20 日受理

*1 秋田赤十字病院整形外科, *2 リハビリテーション科/ $7010-1495$ 秋田県秋田市上北手猿田字苗代沢 222-1

Department of Orthopedic Surgery, ${ }^{* 1}$ Department of Rehabilitation, ${ }^{* 2}$ Akita Red Cross Hospital 
後療法は 1 週間の床上安静とし, 看護婦による仰臥位 と両側臥位の体位変換のみ許可した，床上で仰臥位で の下肢伸展挙上や膝立て訓練を指示した。術後 7 日目 に起立予定とした。術後経過は, 術後 1 日目に両下肢 のしびれ痛みが軽減し徐々に下肢筋力が回復し, 術後 5 日目に滕立て可能となった。術後 6 日目にリ八科紹 介となり理学療法士による下肢筋力評価を行った。ま ず, 理学療法士が疼痛や知覚障害等の問診をした後, 他動的な股関節, 膝関節運動および下肢伸展挙上運動 を両側 1 回施行, その後仰臥位で股関節, 膝関節の自 動運動をさせた。 次に両側腸腰筋, 大腿四頭筋, 前脛 肖筋の 1 2 秒間の等尺性抵抗運動を行い MMT が 3 以上であることを確認した. 同様に下腿三頭筋に等尺 性抵抗を与え MMT が 3 以上であることを評価した 直後, 突然意識消失, 頸部伸展位, 上肢屈曲位となり いびき様呼吸となり心肺停止した。胸部 X 線（図 1 a), 心電図 (図 1 b), 心エコーで右心負荷所見を認 めた. $\mathrm{LDH}$ が $2,101 \mathrm{U} / l$ と高值, 血液ガス分析は, 酸素分圧低下, 二酸化炭素分圧上昇を示した. 直ちに 蘇生術を行い心拍動再開したが, 頭部 CT（図 1 c) で低酸素脳症による脳浮腫を認めた。脳出血を除外診
断し抗凝固療法を施行した. 術後 7 日目に心停止し死 亡した．家族の意向により病理解剖は行わなかった。 臨床所見および除外診断から死因は肺塞栓症と推察し た.

症例 $2: 80$ 歳女性, 1998 年 5 月 20 日転倒受傷. 同 年 5 月 21 日股関節痛のため動作困難となり, 当科入 院し, 左大腿骨頸部骨折の診断で直達牽引を施行し た. 1992 年に真性心室瘤で開心術および右大腿骨頸 部骨折で骨接合術の既往があった。入院時現症は身長 $145 \mathrm{~cm}$, 体重 $61 \mathrm{~kg}$ で肥満を認めた. 入院時血液生 化学検査は異常なかった。翌日手術予定としたが，入 院時心電図に虚血性 ST 変化があり，心エコー検査な ぞの心機能評価を要したため手術を延期した。手術直 前まで疼痛に応じたギャッチベッド起座を許可し両上 肢挙上と両足関節自動運動を指示したが，不穏状態や 痴呆症状が出現したため訓練は進まなかった。深部静 脈血栓症を疑う下肢腫脹は認めなかった。受傷 6 日目 上肢挙上訓練中に突然口より泡様疾を出して意識消失 し呼吸停止した。直ちに蘇生術を開始した。動脈血分 析は, $\mathrm{PaO}_{2} 53.1 \mathrm{mmHg}, \mathrm{PaCO}_{2} 24.7 \mathrm{mmHg}$ と低 酸素，低二酸化炭素血症を呈した。臨床症状扔よび肺 a

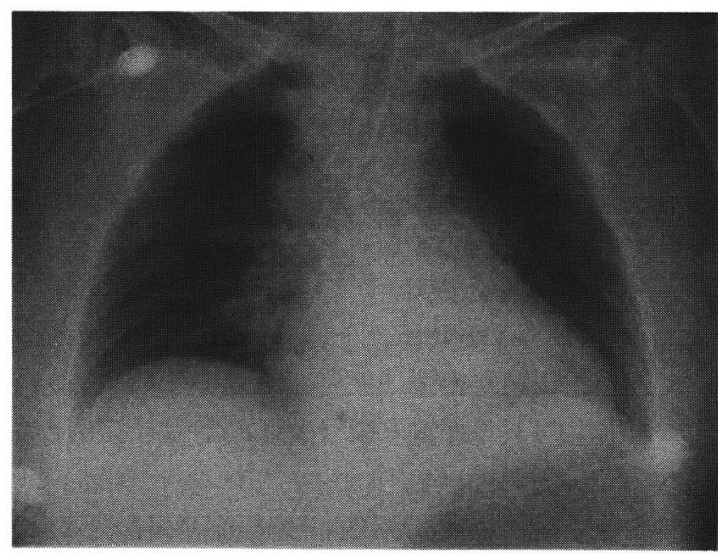

b

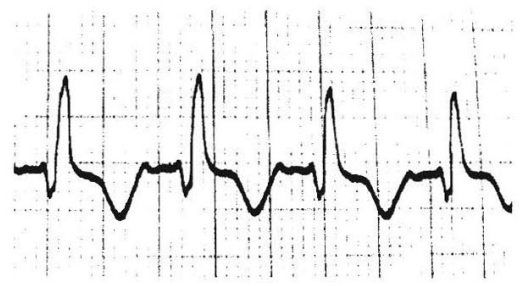

C

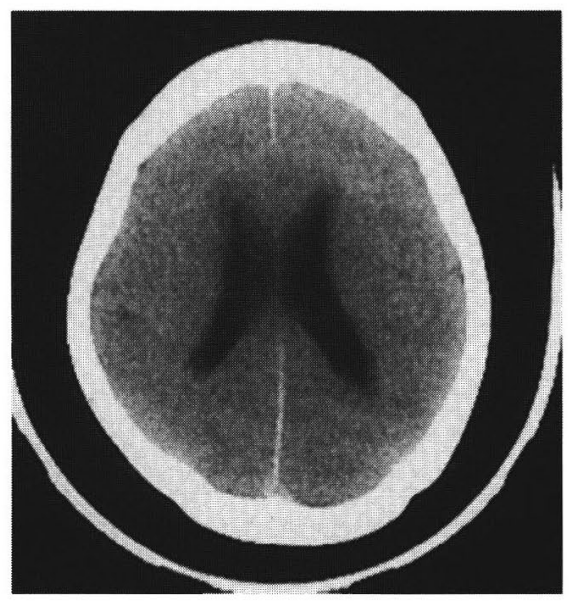

図 1 症例 1 の心肺停止後の所見

$\mathrm{a}$ : 胸部 X 線, $\mathrm{b}$ ：心電図は右心負荷を認める, $\mathrm{c}$ ：頭部 CT で脳出血は否定されたが，脳浮腫を認める. 
a

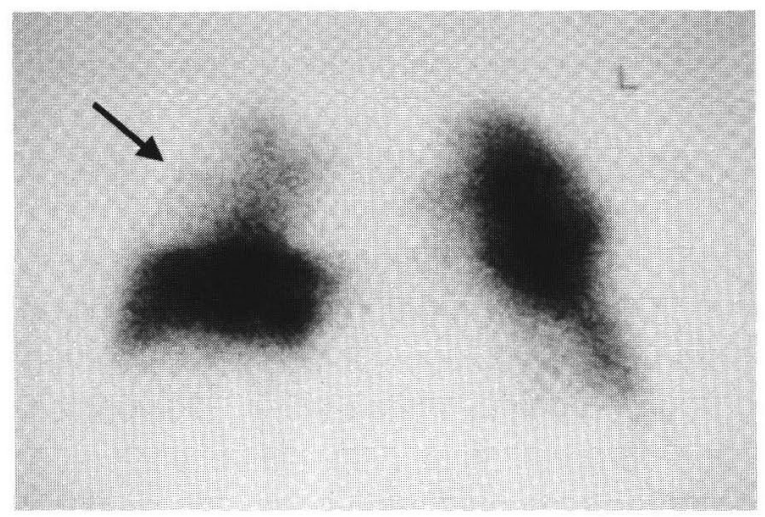

b

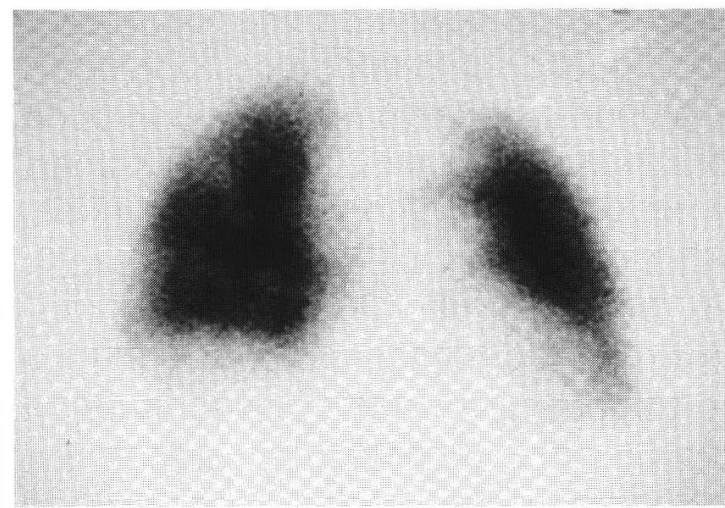

図 2 症例 2 の肺塞栓症治療前後の肺血流シンチグラム $\mathrm{a}$ : 肺塞栓症発生直後, $\mathrm{b}$ : 治療開始後 2 週間.

血流シンチグラム（図 $2 \mathrm{a}$ ）で肺塞栓症と診断し，頭 部 CT で脳出血を否定した上で抗凝固療法（ヘパリ ン）を施行した。受傷 7 日目に意識清明となり受傷 19 日目骨接合術を行った。治療後の肺血流シンチグ ラムでは右肺上葉の欠損部に血流が再開した（図 2 b).

\section{考察}

肺塞栓症の危険因子は，肥満，臥床，高齢，下肢の 麻痺, 心疾患, 脳血管疾患, 下肢の外傷, 経口避妊薬 の内服などとされる4). 症例 1 では, 肥満, 臥床, 下 肢の麻痺を認め, 症例 2 では, 肥満, 臥床, 高齢, 心 疾患, 下肢の外傷などの危険因子が存在した。本症に 特徴的因子ではないがこれらの危険因子を多く持つ患 者には術前より特に注意を要する。

周術期の肺塞栓症の診断やスクリーニングとして受 傷後あるいは入院時からの動脈酸素濃度の意義を述心゙ る報告もあるが，発症の臨床症状により差があり明確 ではない3．呼吸停止に至らない場合には，動脈血分 析で低酸素, 低二酸化炭素血症を認めることが多いと されるが特徵的ではない. 意識消失を認める脳血管疾 患や心疾患を除外した後, 確定診断には肺血流シンチ グラムや肺動脈造影が必要となる ${ }^{3}$. 特に治療に際し 抗凝固療法が禁忌である脳出血は頭部 CTにより除外 する必要がある。

深部静脈血栓症と肺塞栓症との関連性については 種々の報告があるが，明らかではない。実際には本症 例のように肺塞栓症発症時に下肢の腫脹, 疼痛, 発赤
などの深部静脈血栓症に典型的な下肢症状を示さない 場合も多くあり, 深部静脈血栓症の存在の有無により 肺塞栓症の発生を予測することはできない.

平賀ら ${ }^{3)}$ は，骨盤下肢手術前後に肺血流シンチグラ ムを施行し $39 \%$ に肺塞栓が証明され，肺塞栓が発生 した症例のうち無症候性が $94.9 \%$ であったと報告し ている.この事実は, 術後肺塞栓の発生はまれではな く, 周術期において肺塞栓症は術前説明事項の 1 つで あることを示唆している.

肺塞栓症の発生頻度については，人工股関節および 膝関節術後の欧米における報告が多い. 1970 年代に 1〜2\%だった THR の致死的肺塞栓症の発生率は, 手 術および麻酔手技の進歩により 1990 年代には $0.5 \%$ に低下したとされ，さらに抗凝固療法などの予防によ り発生率は $0.18 \%$ 以下になった ${ }^{11}$. 本邦では, 島垣 ら5) が新潟県内関連病院における 1993〜1995 年の 3 年間の THA 件数と術後致死的肺塞栓症例数を調查 し， 636 件中 3 例で $0.16 \%$ であったと報告している. 春椎手術における致死的肺塞栓症の報告例は少ない. 当院の 8 年間の脊椎手術 714 例中致死的肺塞栓症は 1 例で発生率は $0.14 \%$ であった。

肺塞栓症の発生率は低いが重篤で致死的であるため 予防が重要である ${ }^{1,2)}$. THR や TKR の際, 肺塞栓の 予防に米国ではワーファリン，欧州ではへパリンを使 用する施設が多い. 最近, THR 4,088 例と大腿骨頸 部骨折 13,356 例に対しアスピリンの予防効果に関す る randamized study が行われ，アスピリンの使用に より致死的肺塞栓症が $0.6 \%$ から $0.3 \%$ に半減し 
た ${ }^{6)}$. 現在, 本邦でも THR と TKR に対しへパリン 製剤の治験が進行している. しかし, 症例 1 のように 脊椎手術後の場合には術後血腫による神経麻痺の報告 もあり予防薬の使用は制限される。

理学, 運動療法による予防は, 出血のリスクがない という最大の利点を持つ. 足関節自動運動だけでも大 腿静脈血流を $75 \%$ 上昇させるため, 下肢静脈血流を 維持し血管内凝固を予防できる7). 理学, 運動療法 は, 外傷あるいは手術直後から疼痛に応じて選択可能 であり積極的に指導する必要がある。

術中より凝固活性は上昇し術後 24 時間以降も持続 することから ${ }^{8)}$, 術中から術直後に弾性ストッキング やフットポンプなどの pneumatic compression devices を利用することは静脈環流の停滞を防止する可 能性がある. 周術期に pneumatic compression devices を利用すると致死的肺塞栓症の発生が減少し, この機序として静脈環流の改善と二次的に線維素溶解 能の亢進が考えられる ${ }^{1,2)}$. 術直後から利用できる機 器として continuous passive motion (CPM) などが ある. CPM は関節拘縮の予防だけでなく, 関節の持 続的受動運動により深部静脈血栓症の発生を低下させ る効果がある.

術後の歩行訓練開始の際に肺塞栓症が起こることが 報告されている．これは歩行による下腿三頭筋の収縮 や荷重による足底アーチの伸張により静脈環流が増大 するため, 術中から数日間に下肢に発生した血栓が遊 離し肺塞栓を起こすと推測される ${ }^{1,2)}$. 下肢麻痺を呈 した症例 1 は，急激な下腿三頭筋の収縮により発症し ており，同様な機序で肺塞栓を引き起こした可能性が
ある. 今後は, 早期離床, 周術期理学・運動療法や pneumatic compression devices などの機器の利用に よる早期リハビリテーションが必要であると考えられ る.

\section{文献}

1) Salvati EA, Sharrock NE, Murray DW, Westrich $\mathrm{GH}$ : Recent advances in various thrombolic prophylaxis during and after total hip Replacement. J Bone Joint Surg $2000 ; 82-\mathbf{A}$ : 252-270

2) Prentice CRM: Thromboprophylaxis-which treatment for which patient? J Bone Joint Surg 2000; 82-B : 483-485

3）平賀康晴, 立花新太郎, 弘田 裕, 千代倉吉宏, 杉山恵一 朗, 須田雅人：下肢手術後肺塞栓の発生頻度. 日整会誌 1997; 9: 399-402

4) Herzog JA : Deep vein thrombosis in the rehabilitation client. Rehabil Nurs $1992 ; 17$ : 196-198

5）島垣 斎, 松原 統, 成沢弘子, 坪川直人, 冨田 茂: 人 工股関節置換術後に発症した致死的肺塞栓症の 2 例. 新潟整外研会誌 $1996 ; 12: 121-124$

6) The Pulmonary Embolism Prevention (PEP) Trial Collaborative Group: Prevention of pulmonary embolism and deep vein thrombosis with low dose aspirin: pulmonary embolism prevention (PEP) trial. Lancet $2000 ; 355:$ 1295-1302

7) Markel DC, Urquhart B, Derkowska I, Salvati EA, Sharrock NE: Effect of epidural analgesia on venous blood flow after hip arthroplasty. Clin Orthop 1997; 334: 168-174

8) Gitel SN, Salvati EA, Wessler S, Robinson HJ, Worth $\mathrm{MH}$ : The effect of total hip replacement and general surgery on antithrombin III in relation to venous thrombosis. J Bone Joint Surg 1979; 61-A : $653-656$ 